International Journal of

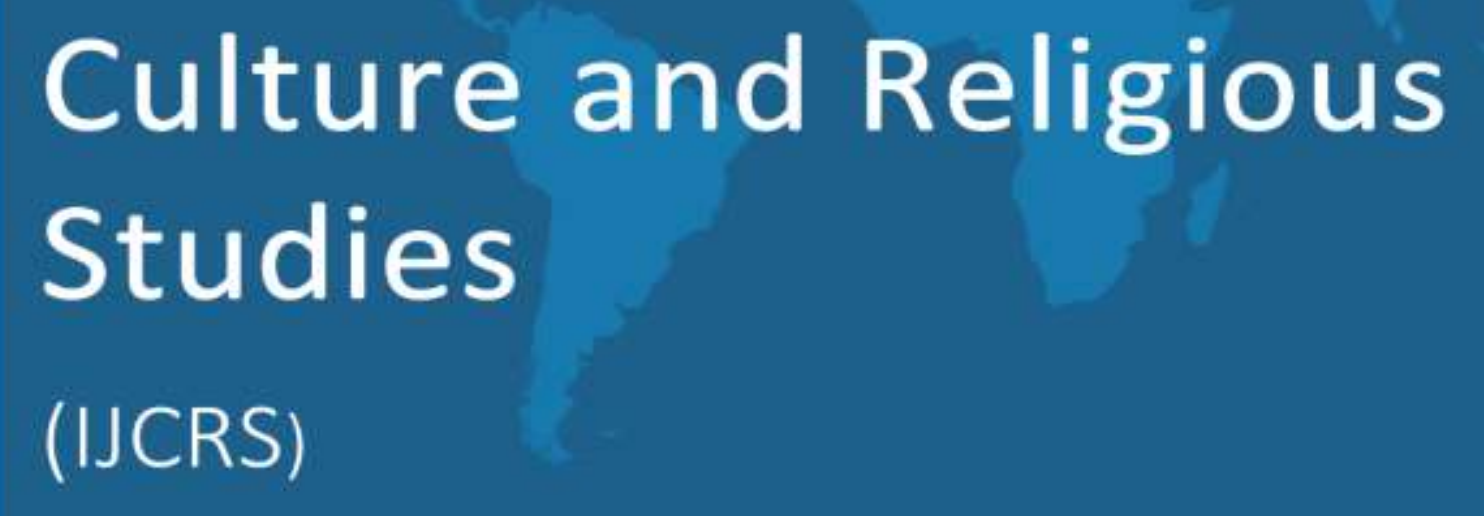

Culture and Religious

Studies

(IJCRS)
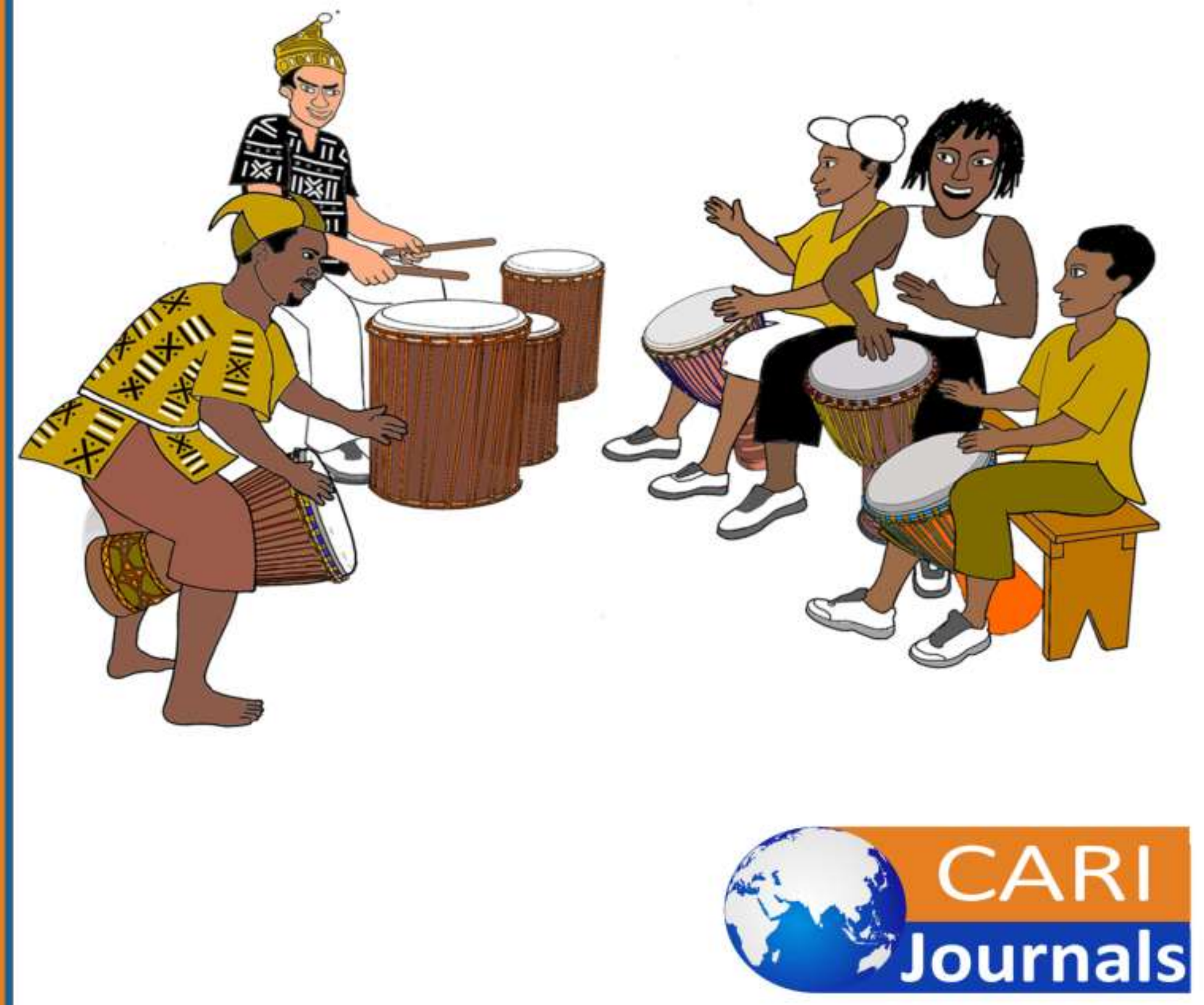


\title{
The nexus between traditional African belief and pandemics: the manifestation of nyawawa spirits amidst the spread of corona virus in the Lake Victoria basin, Kisumu, Kenya.
}

$1 *$ Catherine Akinyi Sewe

Department Of Social Studies, Jaramogi Oginga Odinga University of Science and Technology

*Corresponding Author's Email: catherineolwande@gmail.com

2* Dr Charles Oduke

Department Of Social Studies, Jaramogi Oginga Odinga University of Science and Technology

3* Dr. George Odhiambo

Department Of Social Studies, Jaramogi Oginga Odinga University of Science and Technology

4* Dr. Hezekiah Obwoge

Department Of Social Studies, Jaramogi Oginga Odinga University of Science and Technology

\begin{abstract}
Purpose: The purpose of this study is to better understand the relationship between traditional African beliefs and the prevalence, manifestation, and management of the COVID-19 pandemic among the Luo of Kisumu, Kenya. COVID-19 has had an impact on practically all of the world's continents, including Africa, since its emergence in Wuhan, China in December 2019. As the number of cases and deaths reported internationally continues to rise, everyday real-time reporting of the COVID-19 epidemic has heightened terror and anxiety among the public. There is still a lot we don't know about this condition. Authorities and scientists still don't have all of the answers to the many issues that have been raised. Because medical therapies for COVID-19 are now restricted to supportive measures aimed at easing symptoms, as well as the utilization of research medications and therapeutics, it is believed that patients will easily turn to a greater power than themselves to find hope in an otherwise bleak situation. Spirituality and religious coping become a credible option for resolving the issues of COVID-19 in Africa because the influence of religion in crisis situations cannot be neglected in Africa. The soothing impact of religion in dealing with the COVID-19 situation, has been examined in this study among Luo clans in Kisumu, Kenya. The rich religious affiliation of the Luo community gives them an opportunity to explore a faithcentric response to the pandemic individually and collectively.
\end{abstract}

Methodology: This article used Pargament's theory of religious coping to examine the coronavirus pandemic and traditional African beliefs and practices. Because Nyawawa Spirits are linked to Lake Victoria, the region has been purposefully designated. Data was collected using descriptive survey approaches such as Key Informant Interviews and Focus Group Discussions. A convenient sample of 23 respondents was chosen and interviewed on purposively. Five elders from the Luo Council of Elderss, five religious leaders from African Spirituals churches, five traditional specialists - traditional healers, five elders over the age of 70, and three chiefs from three sublocations are among the 23 . All of these respondents were chosen because they are considered 
to be custodians of Luo traditions and practices, and hence are relevant in providing the essential exposure to the study's topic.

Findings: Following a number of other expressions of traditional beliefs and behaviors demonstrated by many Kenyan groups throughout the pandemic, this study is valid. The findings demonstrate that, rather than attributing coronavirus occurrence solely to traditional beliefs and spirituality, the majority of respondents saw it as a public health risk that should be addressed with precautionary measures. They believe that the government's restriction on social gatherings, which has harmed religious ceremonies such as burial rites, is the proper thing to do and that it is not only directed against religious and ethnic groups. Most religious leaders, on the other hand, think that some religious rituals, such as the celebration of death through elaborate rites, provide individuals with "necessary" emotional and spiritual support. Even if they are sick with the coronavirus, respondents feel that the religious rites they do can heal them.

Unique contribution to theory, practice and policy: The research fits into a unique academic niche, emphasizing how African spirituality is frequently used as a religious coping mechanism for understanding and dealing with difficult life experiences that are linked to the sacred. As a terrible and highly unanticipated event, the COVID-19 crisis fits all of the criteria for generating religious coping mechanisms. While existing works in this thematic specialization, namely human response to pandemics, have frequently emphasized the effects of modern scientific and nonreligious variables, the uniqueness of this work is its alternative perspective, which focuses on covert religious mechanisms used by some African societies in the face of pandemics such as COVID-19.

Keywords: Religious coping, Spirituality, Malevolent spirits, Luo, Pandemic

\section{Introduction}

The relationship between traditional African beliefs and pandemics is critical in evaluating the various management measures used. According to several surveys, the majority of people in SubSaharan Africa do not follow the World Health Organization's (WHO) and individual country health departments' prescribed health and safety precautions. Noncompliance in Kenya is attributed to spirituality, ignorance, and misinformation, raising questions about people's perceptions and practices regarding COVID-19.

When the coronavirus pandemic began in Wuhan, China in December 2019 (Pan, Y., \& Xia, 2020), the social relations between people and communities all over the world were completely altered due to the fact that several key characteristics of COVID-19's transmissibility and natural history were unknown (Russell, et.al,2020), as well as dubious or even false information about factors related to virus transmission (Ornell,et.al, 2020). These actions contradicted African philosophy, which holds that the African is a community person by nature, and that communalism is one of the African cultural ideals. 
Scholars such as Marx, Durkheim, and Freud previously prophesied that as nations modernize, religion would fade away (Meštrović, 2017). This has not occurred, as evidenced by the recent impact of religion on the lives of the majority of the world's population. "Today, 83 percent of the whole population believes in God, and the importance of religion is strengthening in various societies," writes Bentzen (2020). (p. 1). Barrett and Johnson (2001), cited by Koenig (2009), noted that "despite amazing developments in technology and science, 90 percent of the world's population engages in some type of religious or spiritual activity today" (p. 283). This indicates that religion has served a purpose that modernisation has failed to fulfill. As a result, despite growing secularization, religion, churches, and denominational groups have an impact on individual ethical choices and economic decisions,

Religion is an inextricably linked component of African life. As a result, according to Mbiti (2015), Africans are notoriously religious, and religion pervades all aspects of life to such an extent that it is difficult or impossible to isolate it. According to Koenig (2009), persons who do not follow any religion make up less than 0.1 percent of the population in numerous African countries. Although traditional religion provided the foundation for African religious consciousness, Christianity and Islam have given it new energy. Almost all human activities and conditions, including health and disease, are viewed and experienced through the lens of religion in Africa. As a result, Africans frequently turn to religion in times of despair, calamity, fear, and uncertainty. Humans have a tendency to resort to religion for consolation and explanation in times of crisis.

In most African communities, illness and personal spirituality are fundamental notions. Spirituality is described as "a dimension of being that gives life meaning through a personal quest for understanding the ultimate issues about life, and about relationships with the sacred or transcendent," according to Roger and Hatala (2017; 6). Spiritual well-being is an important aspect of personal well-being (Chirico, 2016). Spirituality evokes in health-care recipients the sources to locate the essential inner strengths, such as perspective thinking, rituals for transcending immediate physical state, and methods of coping with their illnesses, according to epidemiological statistics from developing countries (Biberman \& Tischler, 2008).

Consequently, during pandemics, religious/spiritual intervention and management strategies have been secretly adopted to reinforce the patient's positive symptoms in relation to the disease, to the way they deal with limitations or problems during the pandemic, to optimize their therapeutic adherence to pharmacological and non-pharmacological approaches, as well as empowering the patient in other spheres (Bacon \& Jones, 2018).

These advantages, however, were not available in every location or to all patients. They were usually seen in patients who had strong spiritual ties/practices and were willing to believe/perform the prescribed rituals. Patients with psychiatric problems, such as severe psychoses, whose link to reality has been disrupted in some way, will not be able to profit from the aforementioned advantages (Pargament, et.al.2013).

Long before the arrival of Christianity, these processes were a part of the African worldview. There was no phenomenon in Africa that was not given a religious meaning, for example, an owl wailing in the villages during the day would be seen as a bad omen by the inhabitants. While this is the case, the concept of African Traditional Religious Ontology has not only been misinterpreted, but 
has also been a contentious topic of discussion (Marumo, 2016). This may be due to bias on the part of the African elite and western researchers, who had a limited understanding of African cultural history and, paradoxically, compared African religious rituals and conceptions to Christianity. Similarly, anthropologists who relied on generalizations and, in some cases, experiences from specific communities and localities in Africa to draw conclusions about the ontology of God, divinities, and spirits in Africa due to a lack of in-depth study of African religion by anthropologists who relied on generalizations and, in some cases, experiences from specific communities and localities in Africa (Ekeke, Chike, 2010).

This misperception has been dispelled thanks to studies conducted by indigenous African scholars such as Mbiti, who set out to disprove some of the false assertions made about African faiths. He gave Africans their religion and established that Africans displayed their beliefs in various ways based on their cultures. Mbiti also stated that Africans knew God before the missionaries arrived to smash, destroy, and disintegrate their faith and integrity (Mbiti, 2015). According to researchers such as Mbiti, Idowu, and Bolaji, Africans believed in the existence of a supreme entity known as God, as well as other spiritual creatures such as divinities, common spirits, ancestor spirits, and human spirits. Other spirits, who operated in a hierarchical order, were used to worship God (Ekpatt, 2021). At the moment, the world is being ravaged by a virus known as Coronavirus Disease. It's more commonly known as (COVID-19). There is currently no cure or effective therapy for the pandemic. The virus has wreaked havoc on the entire world, disrupting practically all of our social habits. As a result, halting the spread of this infectious disease is critical to protecting global health (Vos, 2021). Because the influence of spirituality on health is a phenomenon resulting from several factors such as lifestyle, social support, a belief system, religious practices, ways of expressing stress, spiritual direction, and guidance, spirituality can be a tool to face the negative symptoms that appear in patients in the COVID-19 context. As a result, certain patients may benefit more from spiritual practices if they clearly believe in the rites (Rodrigues-Pinto \& Oliveira, 2020).

In some societies, spirituality serves as a technique for controlling people's life-threatening diseases, according to Panzini et al. (2007). This is due to the fact that it provides peace of mind and increases a feeling of purpose and meaning in life, which is often linked to the management of anxiety caused by diseases. In African communities, personal beliefs characterize conditions of hardship. Diseases, for example, are referred to as "spiritual encounters" as well as bodily and emotional experiences. The search for a sense of purpose in life, as well as understanding of one's relationship to God and others, appear to be crucial in dealing with a variety of disorders (MoreiraAlmeida \& Koenig, 2010).

Traditional African beliefs, on the other hand, claim that while believe in spirits has an impact on one's health, there are good and harmful spirits. The Banyarwanda, for example, created homes for the spirits they called Bazimu beneath their huts. These served as family shrines where tribute was given to the spirits on a regular basis. Libation was also given to the benign Spirits in order to invite them to the family's celebrations (Bujo, 2005). The hated Spirits, on the other hand, would be exorcised by experts such as diviners, mediums, and traditional healers. The Ghanaian Akan believed that ailments in humans were caused by spirits (Opare-Henaku \& Utsey, 2017). Similarly, 
International Journal of Culture and Religious Studies

Vol. 2, Issue No. 1, pp 79- 96, 2021

Www.carijournals.org

Orawo (2002) describes how the Luo of Kenya employed music and dancing to appease Juogi spirits.

The Luo also believed in roaming spirits, malevolent spirits that might create bad omen and be controlled by witches to cause havoc and even death, which explains why some clans and religious organizations among the Luo of Kisumu have linked diseases like COVID-19 to spirits (OcholaAyayo, 2002). Nyawawa Spirits are nightmarish marauding spirits that are said to originate from the lake. These Spirits, according to Ochola-Ayayo (2002), caused Smallpox, Fever, Pneumonia, Bronchitis, Asthma, and Measles, as well as leaving a path of death wherever they were encountered. Because of this, the Luo pursued these Spirits in a procedure known as goyo Nyawawa, which literally means "beating Nyawawa." The method was marked by striking metallic objects in the hopes of frightening the unwelcome Spirits and causing them to flee the settlements quickly. They were apparently returned to the lake, which was thought to be their home and where no one resided, preventing them from posing a threat to anyone.

Problem statement: Although there are numerous studies in the literature regarding the management of the COVID-19 pandemic as a transmissible infectious disease (Abuya \& White, 2020; Aluga, 2020; and Odhiambo \& Ngare (2020), none has explicitly focused on the sociological assessment of COVID-19 in terms of spirituality, and the use of spirituality to deal with the COVID-19 pandemic is still uncertain (Cavaliere, 2021). Some researchers, however, believe that spirituality is a frequent approach for people to cope with disease. According to some studies, 65 percent of patients with depression, anxiety, and other psychiatric disorders want spirituality to play a role in their therapy (Stewart \& White, 2005). As a result, the goal of this study was to investigate the link between traditional African belief and pandemics based on traditional Luo perceptions of the manifestation, impacts, and control of nyawawa spirits in the Lake Victoria basin, Kisumu, Kenya, during the spread of the corona virus. As a result, in order to comprehend the many spiritual overtones associated to the coronavirus occurrence, this study provides a sociological investigation of the relationship between spirituality and COVID-19 among traditional African civilizations.

\section{LITERATURE REVIEW AND THEORETICAL FRAMEWORK}

Religion is an important aspect of African culture. According to John Mbiti, the African is incurably religious since it is a part of his daily life. His relationship with his creator, in whom he seeks a bond, blessings, and the weapons to confront evil, will be shattered if he does not do so. As a result, religion is an integral aspect of African culture (Mbiti). "Religion is a tremendous effect in religious societies," says Agbo (2019:56), "such that beliefs and tenets formed in the religious sector often cross over into the political and socio-economic arena." However, during the testing period of the Covid-19 epidemic, the silence of faiths and their leaders left a nagging question in the minds of the people. The most common and easily answered questions in people's minds are: Where is God? Where is the claim that some religious leaders make regarding divine and spiritual possession/influence? The deep belief in spirits that pervades African behavior and activities provides answers to such concerns (Nneke \& Onyekelu, 2020).

In contrast to this notion, humans in the modern order are guided by a modern belief that they can rule and control the earth through advancements in knowledge, science, and technology. As a 
result, many people around the world have become atheists or agnostics. Many countries around the world, particularly industrialized ones, have erased the concept of God and given God no place in human thought and history, resulting in the degradation of human values and dignity (Collins, 2006).

An alarming rise in immorality such as fornication, adultery, and rape in countries all over the world is a clear indicator that humanity has disobeyed God's inviolable rules. In terms of longevity and abominations, the current age appears to have surpassed Sodom and Gomorrah (Ejike) (2020). The COVID-19 pandemic, on the other hand, has refuted the notion and highlighted humanity's vulnerability to constraints. It has shown that humans are incapable of mastering and managing the earth's complexity and life systems, such as the working of viruses, atoms, electrons, protons, ions, neutrons, and so on (Ejike, 2020). He concludes that the COVID-19 outbreak is a spiritual as well as a health concern that should not be overlooked. The pandemic, as well as various other natural disasters around the planet, are the result of violations of God's Divine and natural rules, which govern humanity.

People have reacted to COVID-19 in a variety of ways, depending on their spirituality and modernity. Such behaviors differ from one person to the other and from one culture to the other. In order to stem the spread, certain African countries have made thorough surveillance and casefinding a priority (Omonisi, 2020). To scale-up testing for COVID-19, South Africa and Nigeria took use of and integrated molecular laboratory diagnostic capability that already existed for specific disease programs such as drug-resistant tuberculosis, Lassa fever, and HIV. While access to diagnostic reagents becomes more challenging, countries such as Ghana pioneered COVID-19 sample pooling, reducing processing time and increasing population coverage (Carbone, 2020).

Across Africa, several meticulous social measures have also been undertaken. Different countries, for example, have closed their borders to prevent international spread and contain local infection. Self-isolation for infected/exposed people was recommended, and case quarantining centers were constructed (Monfared \& Akhoundzadeh, 2020). Different stadiums in Nigeria, for example, have been converted into isolation centers. The University of Port Harcourt Teaching Hospital (UPTH), the University of Lagos Teaching Hospital (ULTH), and other Federal University Teaching Hospitals were designated as treatment centers (Nnorum \& Nwosa, 2019).

In the face of the pandemic, Madagascar's president, Andry Rejoelina, became one of the most vocal supporters of Covid-organics, a herbal tea marketed as an African cure for covid-19. This covid-organics drink is made with Artemisia. The herbal drink is made from Artemisia species, which are used to extract artemisinin, which is used to cure malaria (Omonisi, 2020). Despite the World Health Organization's (WHO) statement that the virus has no known cure, the Madagascan government provided Covid-Organics to several African countries in the spirit of African unity. Due to the African belief that trees and plants may be utilized to cure any sickness, this country adopted the covid-organic diet. In a similar vein, Adeyeye Enitan Ogunwusi, Ooni of Ife, took a drastic step by going inward and recommending the use of traditional remedies to treat the corona virus. The following plants, he claims, are potent and effective enough to heal everyone infected with the virus (Nnorum \& Nwosa, 2019). 
Because of the difficulties in breathing while working, most people in Ekpeye do not follow Covid19 preventative measures of wearing a face mask, according to Godhead (2020). As a result, some people have decided not to travel to Ahoada's major town, where they will be searched. She further stated that they consider hand washing to be a waste of time due to the fact that their primary employment (farming) attracts dirt. Those who do not believe in Covid-19's reality also do not adhere to the social distance norm. The majority of them may have died as a result of the virus, but because they do not believe in it, they rarely go to the hospital for testing and treatment, therefore their deaths may have gone unnoticed by medical staff. However, amid these casual individuals are those who are extremely conscientious and adhere to the rules, avoiding contact with the virus and the resulting consequences.

A spiritual or natural cause might be attributed to ill health in the African culture. According to Otto \& Opuwari (2020), ailment caused by natural causes is usually treated by the herbalist using egboogi (root) or agbo (herbs), however disease caused by supernatural forces is treated by providing sacrifice to appease the mystical spirits. Normally, Africans think that all illnesses can be cured by either man or spirits. They also believe that roots, plants, and other things have medicinal properties and can be used to heal a variety of ailments. Mbiti agrees with this assertion (2015).

Roots, leaves, stems, tree barks, feathers, stagnant waters, clay, animal dung, animal skins, and fins, according to Awolalu and Dopamu (1979), are some of the materials utilized by Yoruba shamans in Yorubaland to treat sick people. "Leaves and other plant products are therapeutic, but they also include mystical and magical powers, making a preparation of leaves best equipped to cope with both natural and provoked illnesses," writes Falen (2018). Religious specialists play a vital part in the practice of traditional medicine, according to Kalu (2015). As a result, he believes that in Africa, plants alone do not cure illness, but that they must be paired with spiritual invocation, which energises the medicinal efficacy.

Since the beginning of the pandemic, the idea that COVID-19 is a foreign, specifically Chinese disease (Kagwe, 2020) has dominated Kenyan communication. This viewpoint could be traced in part to most Kenyan communities' belief systems, which link "abnormal" ailments to punishment for man's sins against natural laws (Rashed \&Galal, 2015). In the case of COVID-19, the theory that the disease began in a Wuhan wild animals' market as a result of human contact with wild meat from bats, snakes, and pangolins has gained traction in Kenya. This was especially true since preliminary (though inconclusive) research earlier in the year seemed to go in this direction (Maron, 2020). Eating bats and snakes is considered not only prohibited among all Kenyan communities, but also a violation of nature's rules (Rashid \&Galal) (2015).

The conspiracy theory linking the disease to geopolitical wars involving the United States of America, China, and Russia was another story about the pandemic's origins. Tanzanian President John Pombe Magufuli was probably the most vocal proponent of this conspiracy notion (Aljazeera, 2020). In a live television broadcast on May 3, 2020, President Magufuli claimed that COVID-19 is fully a foreign conspiracy to keep the deception alive. He claims in the film that the plan was carried out with domestic collaboration from "certain healthcare workers and experts who may have been put on imperialists' payroll." He claims that the West even sent bogus test kits to Africa, 
kits that produced false-positive results, in order to cause alarm throughout the continent (Aljazeera, 2020).

COVID-19 has also been used to maintain the Black immunity narrative, which claims that some sectors of the population, such as persons of African heritage, are immune to illness. Senou, a Cameroonian student studying in China, was reportedly cured with COVID-19, ostensibly due to his dark skin (Zambian Eye, 2020). This developed as a result of widespread reports that the Chinese doctors caring for Senou said he was alive due of his blood genetic composition, which is common among Sub-Saharan Africans. COVID-19 risk narratives have permeated existing social belief frameworks, laying the groundwork for considering race as a risk factor. Kenyans believed they were immune to the sickness. They believed that the African immune system was due to the struggles that Africans undergo on a daily basis, making them hardy and resistant to 'small' infections like flu-like ailments. (2020, Zambian Eye).

In light of the highlights of literature review, what potends is that COVID-19 has influenced varied reactions and interventions in Africa drawing from practical and philosophical in positions. Thus, in order to to understand the response of the Luo community to COVID-19 Pargament's theory of religious coping, which has become well-established in the field of religious studies was applied.

Religion, according to Pargament (2007), is "a process, a search for significance in ways related to the sacred" (p. 32). Spirituality, he says, is a search for the sacred. He went on to say that religion's most important function is spiritual in nature, and that spirituality as a critical component of existence "cannot and should not be explained away," and that it can be thought of as "a greater dimension of human potential" (Pargament, 2007, p. 31).

Religious coping mechanisms, according to Pargament and Raiya (2007), are "means of comprehending and dealing with negative life situations that are tied to the sacred." (p. 23), and religion may contribute to coping in a unique way because it deals with sacred concerns. According to the hypothesis, people turn to religion to cope with adversity and uncertainty. They pray, seek a closer relationship with God and spirits, or use an Act of God to explain the catastrophe. According to Bentzen (2019), misfortune caused by natural disasters motivates individuals all over the world to use their religion more frequently.

Using religion as a coping mechanism is a type of emotion-focused coping in which people try to alleviate the emotional suffering caused by a situation (Lazarus and Folkman, 1984). While religion is used to cope with a variety of events, it is primarily utilized to cope with bad and unforeseen situations (Smith et al., 2000). Bentzen (2019) found that religiosity rises more in the aftermath of unanticipated natural disasters than in the aftermath of more predictable disasters. When people are confronted with perceived unpleasant but predictable events, on the other hand, they are more likely to engage in problem-focused coping, which is targeted at directly addressing the stressor.

The COVID-19 crisis, as a negative and extremely unpredictable event, has all of the characteristics for triggering religious coping mechanisms. People may be stressed by the coronavirus disease pandemic of 2019 (COVID-19). Fear and anxiety over a new condition and what it might mean can be overwhelming, resulting in intense emotions in both adults and children. Social distancing, for example, can make people feel alienated and lonely, as well as raise tension 
and worry. Faith-based responses to pandemics may appear irrational and so unacceptable to people who hold a critical attitude toward religion. Nonetheless, the healing power of religion, particularly for dealing and surviving in times of adversity, is beyond scientific intervention.

Religion may not adhere to the logical scientific way of evaluation, yet it is a potent painkiller that can assist to alleviate pain and suffering. Religion provides a moral perspective on the universe that is distinct from scientific explanations for persons of faith (Kassim, 2020).

\section{COVID-19 epidemic from a biblical and spiritual standpoint}

Aside from the underlying conventional beliefs, certain Christian literature suggest COVID-19 is apocalyptic rather than mundane. The Book of Revelation contains apocalyptic, prophetic, and epistolary narratives of events that will occur at the end of the world. Christians have viewed the book of Revelation as both a thorough account of "the end of the world" and a demonstration of God's will. Pandemics and life loss are linked to the fourth horseman in this book (Dein, 2021).

For some Christians, the fourth horseman has been linked to Coronavirus, and as a result, certain Christian organisations have contributed to the virus's spread by failing to take COVID-19 prevention measures. Rashid (2020), for example, claimed that the Shincheonji church in South Korea was a major contributor to the development of COVID-19 infections. This group is known for its vigorous and elusive evangelism, according to Bostock (2020). Members were told to keep their church membership hidden while the sect's head promised them direct entry into the "New Earth and the New Heaven." They refused to get vaccinated against the virus and were frequently crammed into church sessions. They've also turned down treatment. The church is thought to be responsible for almost 60\% of all illnesses in the country (Bostock, 2020).

The Haredim in Israel are another religious group that has failed to take preventative steps (Halbfinger 2020). This group adheres to traditional Judaism and adheres to the Jewish interpretation of the law and traditions. They also contradict current attitudes and ideals. Except for commercial activity and vital public relations, they restrict access to people from around the world. Because of the country's alarming poverty rate and the fact that many people live in cramped quarters, observing social separation, let alone other preventive measures, would be difficult among this group. According to a Jewish daily, the Haredim make up around one-third of the country's COVID-19 cases, although accounting for about 12.5 percent of the population.

More importantly, according to Zevloff (2020), about $40 \%$ of Bnei Brak inhabitants in Israel may be infected with COVID-19. This could be because their spiritual leaders have urged them to go about their daily lives as usual. In March 2020, 400 people are said to have attended the burial of a Haredi Rabbi in Bnei Brak. This gang was blamed by Israeli media for defying government orders. Their religious views are said to motivate them, since they believe that if they study and pray, they would be able to overcome the coronavirus. COVID-19, they believe, is a rebuke for their lack of religious observance (Halbfinger, 2020).

Similarly, upon returning home from Tablighi Jamaat, the world's largest Islamic missionary crusade, over 16,000 Muslim hajis in Malaysia were accused of spreading COVID-19 to six countries. This crusade stressed living in the time of Prophet Muhammad, which included communal meals and prayer in mosques. Despite the government's opposition to social gatherings, 
about 8,700 people gathered in bivouacs to eat and distribute food to one another. One member stated, "We are only terrified of God, not of the coronavirus." All things, including good health and illness, come from God, according to a member of the ministry of health's staff. As a result, God is aware of everything that happens to them (Beech, 2020).

Others have offered respite from COVID-19 despite the apocalyptic religious ideologies that have resulted in the virus's propagation. These include faith in a loving and caring God, faith in omniscience and omnipotence, and believe in Christ's resurrection, among others (Simon et al., 2020). Religious groups such as temples, mosques, synagogues, and churches have used media such as radio, television, and live streaming to provide alternate ways of providing online services. All of these alternatives lack the benefits of communal engagement and worship on a one-on-one basis. Catholic cathedrals ordered that senior citizen stay at home and skip Sunday mass, which is generally required (Parke, 2020). Muslims have also been asked to observe home prayers and postpone Umrah and Haji (Heren, 2020).

\section{Discussions}

During the implementation of policies aimed at managing the effects of COVID-19, Miji Kenda elders, one of Kenya's most powerful ethnic groupings, performed traditional ceremonies in the community's sacred forest, denouncing the "COVID-19 evil spirit." While the elders refrained from declaring COVID-19 a fiction, they did claim to have a traditional cure for the deadly epidemic, citing the use of herbs to treat a disease with similar coronavirus symptoms that afflicted the region in the 1950s (Ziz, 2020).

During the same time period, elders from the Meru community in Kenya's eastern region staged a cleansing ceremony in a holy forest to prevent the coronavirus from spreading in their area and throughout Kenya. Around Keny, there is a circus in full swing. Such attitudes have increased Kenyan society's proclivity for stigma, making the fight against the human immunodeficiency virus (HIV) epidemic in the previous two decades exceedingly challenging. As a result of denial and a fascination with miracle treatments, millions of lives have been lost (Mukaria \& Mukaria, 2019).

Social separation, for example, is a foreign concept in African society. Africans thrive in social situations, especially during numerous festivities. The elders interviewed in Kisumu frequently spoke about trusting the road and finding their way under the direction of the ancestors (Wawire, 2010). The elders met and came to the conclusion that Covid-19 and the locust epidemic were ill omens for the period. As such, they were a message from the ancestors, indicating that order needed to be restored as soon as possible through seed ceremonies. The fear was that if the rituals were not performed, further pandemics would arise, and the health of their soil and natural cycles would be disrupted, jeopardizing the future of their agroecology farming, which is their main source of income (KII, EL 1, 2020).

On March 16, 2020, fifteen elders from Kisumu Karateng's six clans met to prepare a ritual performance at Abindu shrine. The elders did not wear masks and adhered to other government regulations such as social separation and hand washing. Ogai, the Kisumu Karateng people's spiritual head, and fourteen other elders who work closely with him led the rituals. He performed 
a "Riembo ja Chien" rite, which means "throwing away the ill omen" (KII, SL, 1, 2020). The spiritual leader announced before beginning the rite,

Moving forward, it's critical to recognize that powerful external forces have exploited the Covid-19 crisis to redirect our attention away from answers that come from inside our relationship with Nature and our different cultures. It's past time for us to recognize that the solutions we seek are already embedded in our indigenous cultures and natural surroundings. Our legendary prophets have warned for centuries that damaging our environment would result in sickness and other natural disasters. If we do not pay attention, we will continue to see this.

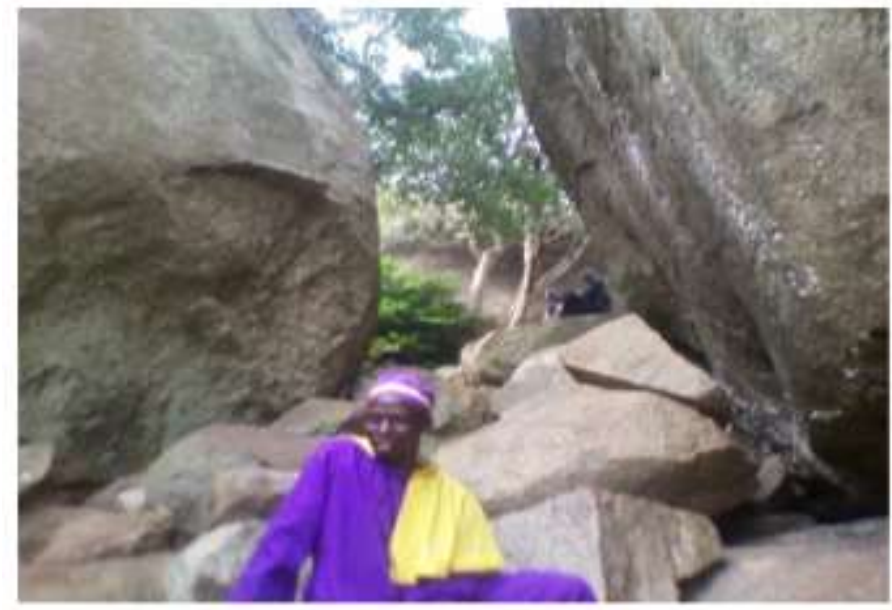

\section{Abindu Shrine.}

The sacred plants of the sodom apple and specific varieties of fig tree known as ngou are used in this ritual. After Ogai had completed praying and condemning the pandemic, the elders tossed the ripe fruits of the sodom apple together with the sticks of ngou in the direction of the Sunset to signify its death and burial (KII, SL,2 Kisumu). They yelled and ran out of the venue without looking back after throwing them. When the elders threw the sticks away, they had to make sure there was no one nearby. All elders who take part in the rite must refrain from sexual activity for four days afterward. They evoke the Sun's (Chieng) and Moon's (Dwe) spirits (due). The Chieng and Dwe are two brothers that are thought to guard Planet Earth. They defend the planet against natural disasters such as the Covid-19. The Sun scoops up the epidemic at nightfall, settles down with it, and passes it over to the Moon to be disposed of in the deep oceans (KII, SL,3).

The Seme community performed identical rites at Kit Mikayi shrine, same as the Kisumu Karateng group did on COVID-19. Kit Mikayi Shrine is said to be linked to the good fortunes of the Seme people who dwell in the shrine area. People visit the shrine for a variety of reasons, including to pray, take oaths, perform rituals and related customs, and to appreciate its natural beauty (KII, SL, 4, 2020). Luo elders would perform ceremonies at the shrine during times of disaster, such as starvation and famine, and rain and abundant harvests would follow. The rituals were led by elderly men and women of high social status; while males participated in activities like as butchering the 
animals, women sang, danced, and prepared the refreshments that accompanied the rituals (KII, CL, 4, 2020).

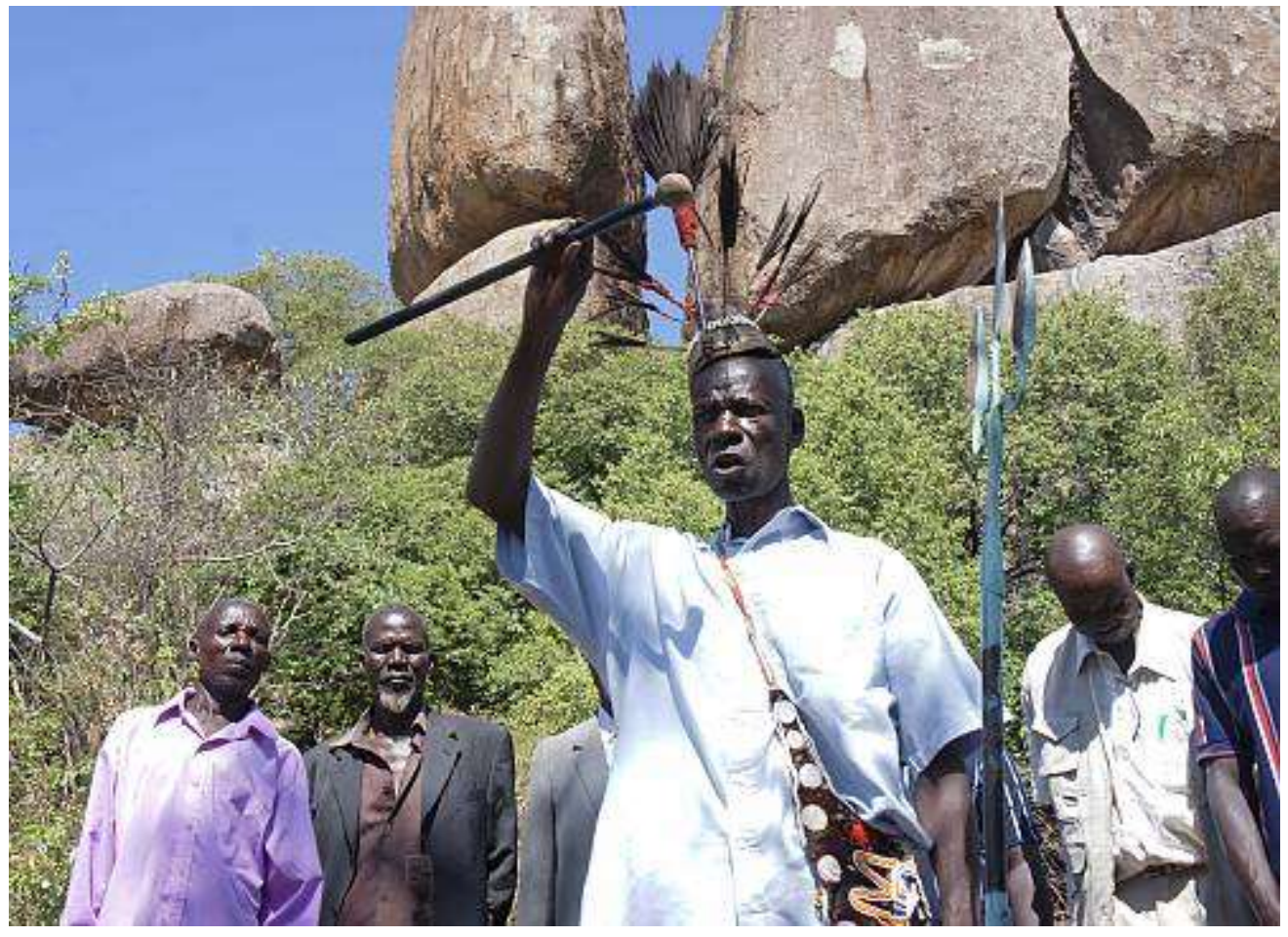

Luo elders performing a ritual to dispel COVID-19 at Kitmikayi shrine on $26^{\text {th }}$ May 2020

For generations, the community has relied on the shrine as a sacred site where they could visit and commune with the Deity, according to an elder. However, the element is now threatened by a number of factors, including decreased enactment frequency, aging bearers and practitioners, and encroachment on surrounding cultural spaces. The fact that the shrine's last major rituals and practices date back to 1987 highlights the danger of their disappearance, with a lack of knowledge prompting a movement toward the shrine's devaluation and defilement as a sacred space for the community (KII, SL, 5, Kitmikayi,2020).

These Spirits, according to Ochola-Ayayo (2002), manifested as a large army of spiritual beings making noises resembling humans, animals, drumming, and driving cows. They sound like a swarm of birds fleeing a cage, according to Stull (2016). When they entered a homestead, they were said to be mostly after the elderly. After being attacked, the elderly men and women were separated from the family's younger members. Some were quarantined in local shrines for traditional treatment and prayers.

In tandem with Ochola-Ayayo (2002), a spiritual leader interviewed in Kitmikay Shrine observed that 
... Nyawawa spirits were not common and in instances when they manifested, particularly with negative effects, the Luo believed that the community had committed some bad practices contradicting the will of the Supreme Being, hence these spirits were communicating with the people especially regarding bad tidings (KII, SL, 1, Seme, 2020).

An FGD, report conducted in Kombewa in May 2020, noted that,

the society in general has committed evil against the will of God. Rape, sorcery, magic, conflicts over land and neglect of widows and orphans have been common experiences among the Luo of Kisumu, hence the spirits as messengers of the Supreme Being have featured in form of COVID-19 (FGD, Kombewa, May 2020).

An elder from the Abindu shrine said that their forefathers react to wicked actions in a variety of ways, but that diseases and tragedies with unknown causes are common. Ekeke and Chike (2010) agree with this argument and point out that when wickedness prevails in African societies, the Supreme Being manifests himself through manevolent spirits such as Nyawawa, inflicting sickness and death among populations. The victims are isolated in special huts in some Luo clans in the region, where instrumental music produced by Ajawa or poko - gourd rattles and vocals were used to exorcise or pacify stubborn juogi spirits that manifested in the form of respiratory complications, restlessness, and high fever, which are similar to the COVID-19 pandemic in this study (KII, 4, 2020). This process was carried out by an expert, such as a medium, according to a traditional medicine woman, and families who did not cooperate lost their loved ones (KII, SL,3, Manywanda, 2020).

Similarly, Owuor and Kokwaro (2006) believed that if homestead members failed to isolate the victims, Nyawawa spirits would enter a home and attach everyone, causing sickness and death. According to their testimony, the Nyawawa Spirits were persuaded that they were facing a massive army of family ancestors because of the music and loudness. The spirits would then modify their course and move on to the next farmstead as a result.

The intervention of elders of the community was key in managing the effects of Nyawawa spirits. According to a clan elder of Kapuonja community

An elder in every homestead would place a big pot in affected households containing special herbs that would be boiled and some burnt and members of the family would be forced to inhale and drink the solution from the pot. This was intended to smoke out the Nyawawa spirits from the affected household as the community believed that the shocked spirits would cry out in confusion as they flee to their abode in the Lake (KII, EL, 1, 2020).

Apart from the spiritual implications, the study demonstrates that individuals are sufficiently aware of the coronavirus epidemic as a public health issue and a sin-related problem. Regardless of their religious convictions, they take precautions and do not feel that religious houses are the goal of the government's social gathering restriction. They do, however, believe that churches and, in some cases, shrines provide 'essential' services such as emotional and spiritual support to the public and, 
as a result, should be open for worship, as many people believe they can receive healing from their place of worship even if they are coronavirus positive.

COVID-19 has had a significant impact on many religious rituals. To prevent the spread of COVID-19, important face-to-face spiritual meetings have been severely constrained; many schools have been closed, and group contacts during carnivals and holidays have been prohibited in Kisumu. This has resulted in numerous spiritual challenges such as anxiety, stress, concerns, and debates over religious matters, which academics expect would worsen if people are unable to worship.

\section{Conclusion}

Similarities between religious beliefs and pandemics were investigated in this research. Both are direct answers to the virus's existential dilemma as well as underlying social imbalances. The fear and worry connected with COVID-19 has gained traction around the world, particularly among the elderly and those with underlying medical issues. The number of cases in Africa has continued to climb, posing a major threat to public health. The continent's underdeveloped health-care system, along with a big population that is immunocompromised due to high rates of starvation, anemia, malaria, HIV/AIDS, tuberculosis, and poor economic discipline, has made pandemic management challenging. However, because some groups and individuals have urged supernatural forces to act on their favor when faced with COVID-19, Africa's extensive religious connection has hampered medical efforts and possibilities to to manage the epidemic. Religious coping may not be a viable choice in dealing with the issues provided by the COVID-19 pandemic in Africa, despite the fact that religion is an inextricable aspect of African society.

\section{Recommendations}

Based on the findings, it was suggested that religious communities alter their attitude to pandemic management and embrace policies imposed by health institutions. Also, among advocates of traditional and religious methods, there is a need to conduct research and provide specific data on the number of infected persons and death rates in order to change the worldview of different religious communities on the effects of the pandemic, reduce the associated fear with the pandemic, and lessen the people's social and religious effects.

\section{REFERENCES}

Abuya, T., Austrian, K., Isaac, A., Kangwana, B., Mbushi, F., Muluve, E., ... \& White, C. (2020). COVID-19-related knowledge, attitudes, and practices in urban slums in Nairobi, Kenya.

Aljazeera. (2020). Tanzania president questions COVID-19 kits after animal test. Available at: https://www.aljazeera.com/news/2020/05/tanzania-president-questions-COVID-19-kitsanimal-test200503174100809.html

Aluga, M. A. (2020). Coronavirus Disease 2019 (COVID-19) in Kenya: Preparedness, response and transmissibility. Journal of Microbiology, Immunology and Infection, 53(5), 671-673.

Awolalu, J. O., \& Dopamu, P. A. (1979). West African traditional religion. 
International Journal of Culture and Religious Studies

Vol. 2, Issue No. 1, pp 79- 96, 2021

$\underline{\text { www.carijournals.org }}$

Bacon, R., Finke, R., \& Jones, D. (2018). Merging the religious congregations and membership studies: A data file for documenting American religious change. Review of religious research, 60(3), 403-422.

Barrett, D. B., Barrett, D., Johnson, T., Johnson, T. M., Guidry, C. R., \& Crossing, P. F. (2001). World Christian Trends Ad30-ad2200 (hb) (Vol. 2). William Carey Library.

Beech, H., 2020. None of Us Have a Fear of corona: the Faithful at an Outbreak's center. New York Times. Retrieved. https://www.nytimes.com/2020/03/20/world/as ia/coronavirusmalaysia-muslimsoutbreak. (Accessed 17 July 2020).

Bentzen, J., \& Gokmen, G. (2020). The Power of Religion.

Biberman, J., \& Tischler, L. (2008). Spirituality in business: Theory, practice, and future directions. Springer.

Bostock, B., 2020. South Korea Is Testing 200,000 Members of a Doomsday Church Linked to More than $60 \%$ of its Coronavirus Cases. Business Insider. Retrieved. htt ps://www.businessinsider.com. (Accessed 17 July 2020).

Bujo, B. (Ed.). (2005). African theology in the 21st century: the contribution of the pioneers. 2. Paulines Publications Africa.

Carbone, G. (2020). Africa's Thorny Horn: searching for a new balance in the age of pandemic. Africa's Thorny Horn, 1-161.

Cavaliere, P. (2021). Religious institutions in Japan responding to COVID-19-induced risk and uncertainty: some preliminary considerations. Journal of Religion in Japan, 10(1), 31-63.

Chirico, F. (2016). Spiritual well-being in the 21 st century: It's time to review the current WHO's health definition. Journal of Health and Social Sciences, 1(1), 11-16.

Collins, F. S. (2006). The language of God: A scientist presents evidence for belief (No. 111). Simon and Schuster.

Dein, S. (2021). Covid-19 and the apocalypse: religious and secular perspectives. Journal of religion and health, $60(1), 5-15$.

Ejike, C. E. (2020). COVID-19, NATURAL EVILS, DIVINE AND NATURAL LAWS. Journal of African Studies and Sustainable Development, 3(12).

Ekeke, E. C., \& Chike, A. E. (2010). God, divinities and spirits in African traditional religious ontology. American Journal of Social and Management Sciences, 1(2), 209-218.

Ekpatt, A. O. (2021). Concepts of God, Divinities, Ancestors, and Spirits in African Traditional Religious Thought: Conceptual Analysis. In Phenomenological Approaches to Religion and Spirituality (pp. 18-43). IGI Global.

Falen, D. J. (2018). African science: Witchcraft, vodun, and healing in Southern Benin. University of Wisconsin Press. 
International Journal of Culture and Religious Studies

Vol. 2, Issue No. 1, pp 79- 96, 2021

www.carijournals.org

Halbfinger, D., 2020. Virus Soars Among Ultra-orthodox Jews as many Flout Israel's Rules. New York Times. Retrieved. https://www.nytimes.com. (Accessed 17 July 2020).

Heren, K., 2020. Muslims should delay making Hajj plans due to coronavirus fears, says Saudi minister. Arabia. Evening Standard. Retrieved July 17, 2020, from. https:

Kagwe confirms the first coronavirus patient in Kenya'. March 13, 2020. Available at: https://youtu.be/ShTQoOzNYVE

Kalu, E. I., Wagbatsoma, V., Ogbaini-Emovon, E., Nwadike, V. U., \& Ojide, C. K. (2015). Age and sex prevalence of infectious dermatoses among primary school children in a rural South-Eastern Nigerian community. Pan African Medical Journal, 20(1).

Koenig, H. G. (2009). Research on religion, spirituality, and mental health: A review. The Canadian Journal of Psychiatry, 54(5), 283-291.

Maron, D F (2020) 'Wet markets' likely launched the coronavirus. Here's what you need to know.

Marumo, P. O. (2016). Christianity and African Traditional Religion in dialogue: An ecological future for Africa (Doctoral dissertation).

Mbiti, J. S. (2015). Introduction to African religion: Waveland Press.

Meštrović, S. G. (2017). Durkheim and postmodern culture. Routledge.

Monfared, A., Balou, H. A., Madani, A. H., Taramsari, M. R., Hemmati, H., Mohammadzadeh, A., ... \& Akhoundzadeh, L. (2020). Management of COVID-19 crisis in Guilan province in Northern Iran. Archives of Iranian medicine, 23(7), 511.

Monfared, A., Balou, H. A., Madani, A. H., Taramsari, M. R., Hemmati, H., Mohammadzadeh, A., ... \& Akhoundzadeh, L. (2020). Management of COVID-19 crisis in Guilan province in Northern Iran. Archives of Iranian medicine, 23(7), 511.

Moreira-Almeida, A., \& Koenig, H. G. (2006). Retaining the meaning of the words religiousness and spirituality: A commentary on the WHOQOL SRPB group's "A cross-cultural study of spirituality, religion, and personal beliefs as components of quality of life"(62: 6, 2005, 1486-1497). Social Science \& Medicine, 63(4), 843-845.

Mukaria, E. M., \& Mukaria, A. R. (2019). The Traditional Understanding of Grief Among Ameru in Kenya. Jumuga Journal of Education, Oral Studies, and Human Sciences (JJEOSHS), 2(1), 1-10.

Nneke, C. A., \& Onyekelu, A. C. (2020). RELIGION OF OUR TIME AND CLAIM TO DIVINE PRESENCE: A PHILOSOPHICAL PURSUIT OF HER SILENCE IN THE COVID-19 PANDEMIC. Journal of African Studies and Sustainable Development, 3(12).

Nnorum, D. A., Otto, O. A., \& Nwosa, F. (2019). AFRICAN MODEL OF APPROACHING THE COVID-19 PANDEMIC. JOS JOURNAL OF RELIGION AND PHILOSOPHY, 1(1). 
International Journal of Culture and Religious Studies

Vol. 2, Issue No. 1, pp 79- 96, 2021

www.carijournals.org

Nnorum, D. A., Otto, O. A., \& Nwosa, F. (2019). AFRICAN MODEL OF APPROACHING THE COVID-19 PANDEMIC. JOS JOURNAL OF RELIGION AND PHILOSOPHY, 1(1).

Ocholla-Ayayo, A. (2002). Culture as a Lived Experience. Population Studies and Research Institute, University of Nairobi.

Odhiambo, J., Weke, P., \& Ngare, P. (2020). Modeling Kenyan economic impact of corona virus in Kenya using discrete-time Markov chains. Journal of Finance and Economics, 8(2), 80-85.

Omonisi, A. E. (2020). How COVID-19 pandemic is changing the Africa's elaborate burial rites, mourning and grieving. The Pan African Medical Journal, 35(Suppl 2).

Opare-Henaku, A., \& Utsey, S. O. (2017). Culturally prescribed beliefs about mental illness among the Akan of Ghana. Transcultural psychiatry, 54(4), 502-522.

Orawo, N. (2012): Healing dance: A case study of the Luo and Dawida Mwanzidika Dances International Journal of Business and Social Sciences, Vol 3 No 2 special issue (January 2012).

Ornell, F., Moura, H. F., Scherer, J. N., Pechansky, F., Kessler, F. H. P., \& von Diemen, L. (2020). The COVID-19 pandemic and its impact on substance use: implications for prevention and treatment. Psychiatry research, 289, 113096.

Otto, O. A., \& Opuwari, S. O. (2020). SOCIO-RELIGIOUS ISSUES IN THE AFRICAN RESPONSE TO THE COVID-19 PANDEMIC: THE OGBA AND ENGENNI PERSPECTIVES. Journal of African Studies and Sustainable Development, 3(12).

Owuor, B., Oketch-Rabah, H., \& Kokwaro, J. O. (2006). Reinventing therapo-spiritual fellowships: The jolang'o in Luo African Independent Churches. Mental Health, Religion \& Culture, 9(5), 423-434.

Pan, Y., Guan, H., Zhou, S., Wang, Y., Li, Q., Zhu, T., ... \& Xia, L. (2020). Initial CT findings and temporal changes in patients with the novel coronavirus pneumonia (2019-nCoV): a study of 63 patients in Wuhan, China. European radiology, 30(6), 3306-3309.

Panzini, R. G., \& Bandeira, D. R. (2007). Coping (enfrentamento) religioso/espiritual. Archives of Clinical Psychiatry (São Paulo), 34, 126-135.

Pargament, K. I. \&Trevino, K. M., (2007). Religious coping with terrorism and natural disaster: Spirituality/Medicine interface project. Southern medical journal (Birmingham), 100(9), 946-947.

Pargament, K. I., Falb, M. D., Ano, G. G., \& Wachholtz, A. B. (2013). The religious dimension of coping: Advances in theory, research, and practice.

Parke, C., 2020. Coronavirus Fight, China Has Not Stopped Persecuting Christians: Watchdog. Fox News. Retrieved. https://www.foxnews.com. (Accessed 17 July 2020). 
Rashed, T. G., and M. Galal (2015) 'Culture and health: A study in Medical Anthropology in Kenya'. Annual International Conference of the Institute of African Research and Studies 'Human Security in Africa', Institute of African Research and Studies, Cairo University, Egypt, 26- 28 May 2015

Rashid, Z.Z., Othman, S.N., Abdul Samat, M.N., Ali, U.K., Wong, K.K., 2020 Apr. Diagnostic performance of COVID-19 serology assays. Malays. J. Pathol. 42 (1), 13-21. PMID: 32342927.

Rodrigues-Pinto, R., Sousa, R., \& Oliveira, A. (2020). Preparing to perform trauma and orthopaedic surgery on patients with COVID-19. The Journal of bone and joint surgery. American volume.

Roger, K. S., \& Hatala, A. (2018). Religion, spirituality \& chronic illness: A scoping review and implications for health care practitioners. Journal of Religion \& Spirituality in Social Work: Social Thought, 37(1), 24-44.

Russell, T. W., Hellewell, J., Jarvis, C. I., Van Zandvoort, K., Abbott, S., Ratnayake, R., ... \& CMMID COVID-19 working group. (2020). Estimating the infection and case fatality ratio for coronavirus disease (COVID-19) using age-adjusted data from the outbreak on the Diamond Princess cruise ship, February 2020. Eurosurveillance, 25(12), 2000256.

Simon, D., Kate, L., Christopher, A.L., Kenneth, I.P., 2020. COVID-19, mental health, and religion: an agenda for future research. J. Mental Health Relig. Cult. 23 (1), 1-9.

Stewart, S. M., Rao, U., Emslie, G. J., Klein, D., \& White, P. C. (2005). Depressive symptoms predict hospitalization for adolescents with type 1 diabetes mellitus. Pediatrics, 115(5), $1315-1319$.

Swami, H. D. G. A. B. (2020). Krsna, the Supreme Personality of Godhead. The Bhaktivedanta Book Trust International, Inc..

Vos, J. (2021). The Psychology of Covid-19. The Psychology of Covid-19, 1-192.

Wawire, S. N. (2010). Negotiating identity: Identity dynamics in the context of male circumcision and HIV/AIDS among Luo youth in Kisumu, Kenya (Doctoral dissertation, Brown University).

Zambian Eye (2020) African Blood Resist Coronavirus. February 15, 2020. Available at: https://zambianeye.com/african-blood-resisit-corovirus/ ; Reuters Fact Check (2020) False Claim: African Skin Resists the Coronavirus

Zevloff, N., 2020. Israeli Haredim, Blamed for COVID Outbreaks, Could See Their Communities Forever Changed. The Forward. Retrieved. https://forward.com/news/ israel/443707/israel-harediultra-. (Accessed 17 July 2020).

Ziz, I. Z. (2020). The COVID-19 Pandemic and Racialised Risk Narratives in Kenya. 